\title{
Kinetics and Thermodynamics Studies of Copper(II) Adsorption onto Activated Carbon Prepared from Salacca zalacca Peel
}

\section{Dewi Yuanita Lestari*, Endang Widjajanti Laksono}

\author{
Department of Chemistry, Universitas Negeri Yogyakarta, Yogyakarta, 55281, Indonesia \\ *Corresponding author email: dewi_yuanita@uny.ac.id
}

Received April 24, 2019; Accepted June 01, 2020; Available online July 27, 2020

\begin{abstract}
Highly porous and stable materials, such as alumina, silica, carbon, zeolite, and bentonite, are well known and have been used as metal ion adsorbents. However, the use of biogenic carbon as adsorbent is relatively rare. The adsorption of copper(II) onto activated carbon extracted from Salcaca zalacca peel was studied. The effect of initial copper concentration, contact time, and a series temperature was studied. Adsorption was carried out in a batch technique. The adsorption equilibrium was reached after 60 minutes of contact time. The adsorption data had a better fitting line for the Langmuir isotherm model. The Langergren and also $\mathrm{Ho}$ and $\mathrm{Mc}$ Kay equations were used to predict the adsorption kinetics. The adsorption process obeyed a second-order kinetics model. The Thermodynamic parameters were $\Delta \mathrm{H}^{\circ}=-42.4180 \mathrm{~kJ} / \mathrm{mol}$; $\Delta \mathrm{S}^{\circ}=-0.0843 \mathrm{~kJ} / \mathrm{mol} ; \Delta \mathrm{G}^{\circ}<0$. These values indicated that the adsorption was exothermic and spontaneous. The low $\Delta \mathrm{G}^{\circ}$ value revealed that the main mechanism controlling the adsorption process was physisorption.
\end{abstract}

Keywords: adsorption, Salacca zalacca peel, kinetic, thermodynamics

\section{INTRODUCTION}

The presence of heavy metals in aqueous streams can be dangerous to organism. The metals are nondegradable and can be toxic to the environment. The heavy metals tend to accumulate in the tissues of living species. It is important to remove heavy metals from wastewater to reduce their impact on the environment. Several methods have been used to reduce heavy metals from aqueous media. The methods include precipitation, ion exchange, ultrafiltration, membrane separation and adsorption (Chao, and Chang, 2018; Liv, Li, Zhi, and Ren, 2017; Fang et al., 2018). The adsorption method is the most popular because of its simplicity, high efficiency, and low cost. Activated carbon was known as an effective adsorbent because of several reasons i.e: its high adsorption capacity, high surface area, and microporous structure (Kolanowska et al., 2018; Kunigk, Dos Santos, and Jurkiewicz, 2011) but commercially activated carbon is expensive. To decrease costs of metal removal from wastewater many research has been done to develop low costs adsorbent.

Low costs activated carbon can be prepared from agricultural waste. Many low costs adsorbent from agricultural waste such as Tamrix articulata (Othman, Hashem, and Habila, 2011), apple peel (Enniya, Rghioui, and Jourani, 2018), barley husk (Osasona, Aiyedatiwa, Johnson, and Faboya, 2018), silk cotton fruit wall (Shanmugavalli et. al., 2007), coconut and seed hull of a Palm tree (Gueu, Yao, Adouby, and Ado,
2006, 2007), orange peel (Mafra, Igarashi-Mafra, Zuim, Vasques, and Ferreira, 2013; Salman, and Ali, 2016), and peanut hull (Jaishankar, Mathew, Shah, Murthy, and Gowda, 2014; Rehab, Hesham, Mohamed, and Gihan, 2016; Brown, Jefcoat, Parrish, Gill, and Graham, 2000) have been investigated. The use agricultural wastes as adsorbent indicate several benefits such as minimizing the unacceptable disposal of agricultural wastes, converting the unwanted agricultural waste to more economical value materials, and reducing the cost of adsorbent preparation (Indhumathi, Sathiyarai, Koelmel, Jayabalakrishnan, and Saravanabhavan, 2018; Kumar , Muralidhara, Nayaka, Balasubramanyam, and Hanumanthappa, 2013).

One of the agricultural waste which needs to be treated is Salacca zalacca peel. Salacca zalacca or Salak (Indonesian) or snake fruit is a tropical fruit widely found in Indonesia. Salacca zalacca is usually used to make food products and beverages. From the food processing, the Salacca zalacca peel are produced and so the biowaste is abundant. This Salacca zalacca peel can be processed to activated carbon and then can be used as adsorbent.

In this study, Salacca zalacca peel was processed to activated carbon and used as an adsorbent to adsorb $\mathrm{Cu}(\mathrm{II})$ ions. The effect of contact time, initial concentration, and temperature were investigated. The adsorption model was determined using Langmuir and Freundlich equations. The kinetics 
model and thermodynamics parameter of adsorption of $\mathrm{Cu}$ (II) onto activated carbon from Salacca zalacca peel were also investigated.

\section{EXPERIMENTAL SECTION \\ Activated Carbon Preparation}

The Salacca zalacca peel was washed with water to remove contaminants, and dried under sunlight for 2-5 days. The dried Salacca zalacca peel was carbonized using a clay pot. The carbon was then crushed and sieved to 50 mesh particles. The carbonized sample was soaked with $1 \mathrm{M} \mathrm{H}_{2} \mathrm{SO}_{4}$ solution for 24 hours followed by washing with aqua dest and then was dried in the oven at $110{ }^{\circ} \mathrm{C}$ for 4 hours.

\section{Adsorption Experiment}

Adsorption experiments were carried out using a batch technique. A $10 \mathrm{~mL}$ of an aqueous solution of $\mathrm{Cu}(\mathrm{II})$ with concentration ranging from 5 to $25 \mathrm{ppm}$ was placed in the beaker glass, stirred for 5 minutes. The adsorption of $\mathrm{Cu}$ (II) on activated carbon were undertaken at $0,5,10,15,20,30,45,60,90,120$, and 150 minutes to determine the equilibrium time. To determine the thermodynamics parameter, adsorption of $\mathrm{Cu}$ (II) onto activated carbon was undertaken at 26, 31, and $41{ }^{\circ} \mathrm{C}$. After the experiment, the adsorbents were separated by filtration using filter paper (Whatman 42). The filtrates were analyzed by an atomic absorption spectrophotometer (Shimadzu). The adsorption capacity was determined using the following equation.

$$
q_{e}=\frac{\left(C_{i}-C_{e}\right) x V}{w}
$$

Where $C_{i}(\mathrm{mg} / \mathrm{g})$ is a concentration of $\mathrm{Cu}(\mathrm{II})$ at time 0 , $\mathrm{C}_{\mathrm{e}}(\mathrm{mg} / \mathrm{g})$ is a concentration of $\mathrm{Cu}(\mathrm{II})$ at equilibrium, $\mathrm{V}$ $(\mathrm{L})$ is the volume of metal ion solution, and $\mathrm{w}(\mathrm{g})$ is the weight of the adsorbent.

\section{RESULTS AND DISCUSSION \\ Adsorbent Characterization}

The characterizations that have been carried out on adsorbent were FTIR and XRD. The FTIR analysis was conducted to investigate the functional groups in activated carbon from Salacca peels. As shown in Figure 1, a peak at $3434 \mathrm{~cm}^{-1}$ is assigned as $\mathrm{O}-\mathrm{H}$ stretching vibration of the hydroxyl group. A peak at $1619 \mathrm{~cm}^{-1}$ belongs to $\mathrm{C}=\mathrm{O}$ stretching vibration in the carbonyl group and this is also attributed to $C=C$ stretching vibration of the aromatic carbon skeleton. A band at $2361 \mathrm{~cm}^{-1}$ is associated with $\mathrm{C}=\mathrm{C}$ stretching. These bands indicate that some lignin, cellulose, and hemicellulose or intermediate structure remained unchanged after carbonization (Semercioz et.al., 2017).

Figure 2 shows the XRD pattern of activated carbon from Salacca peel did not show well-defined peaks, which means that the structure of activated carbon from Salacca peel is completely amorphous. There are broad diffraction peaks around $2 \theta=20-30^{\circ}$ and $40,8444^{\circ}$. This indicates the diffraction of ( 002 ) and $\left(\begin{array}{ll}1 & 0\end{array}\right)$, respectively (Zhigang Xie, Wei Guan, Fangying Ji, Zhongrong Song, \& Yanling Zhao, 2014)

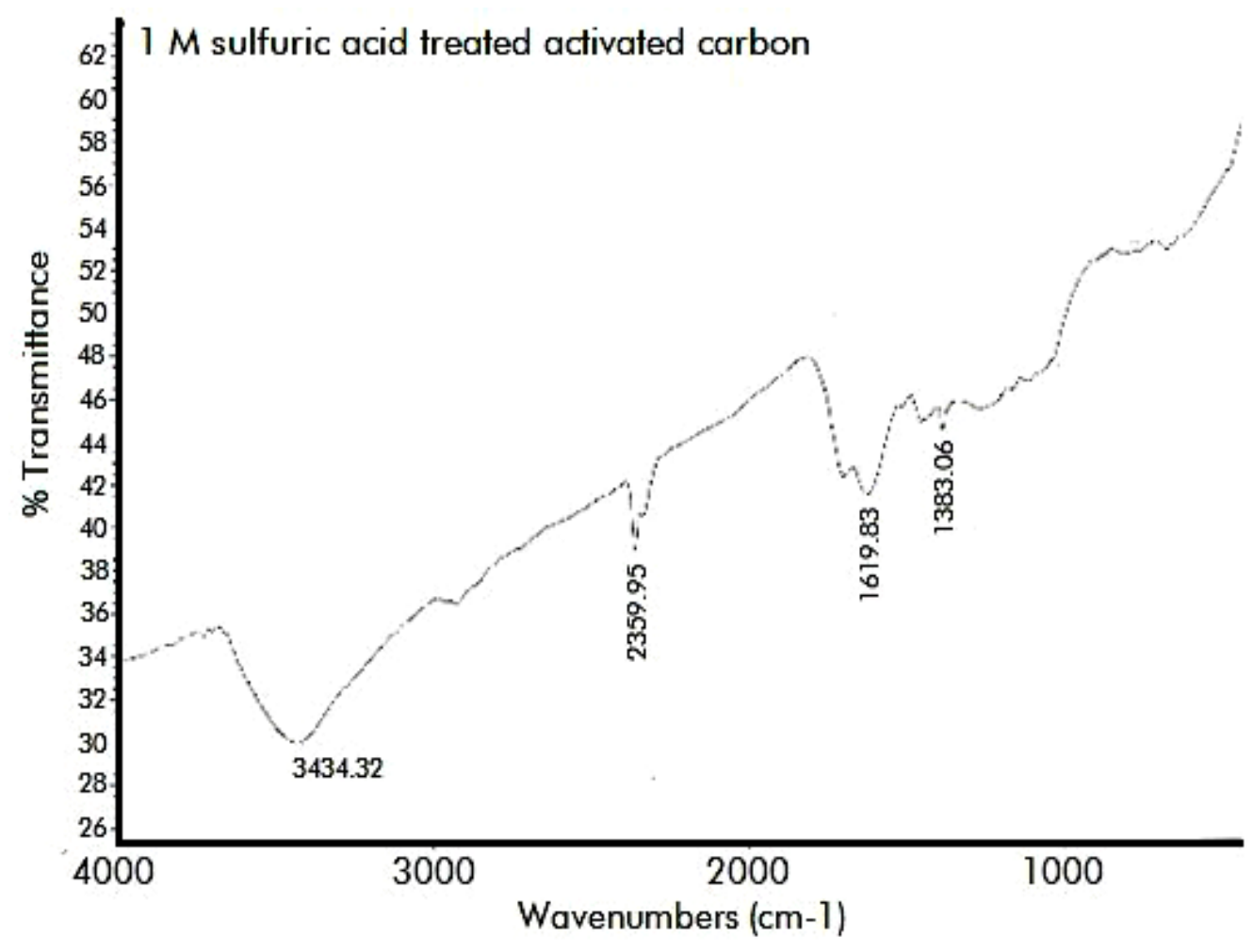

Figure 1. FTIR spectrum of activated carbon from Salacca zalacca peel 


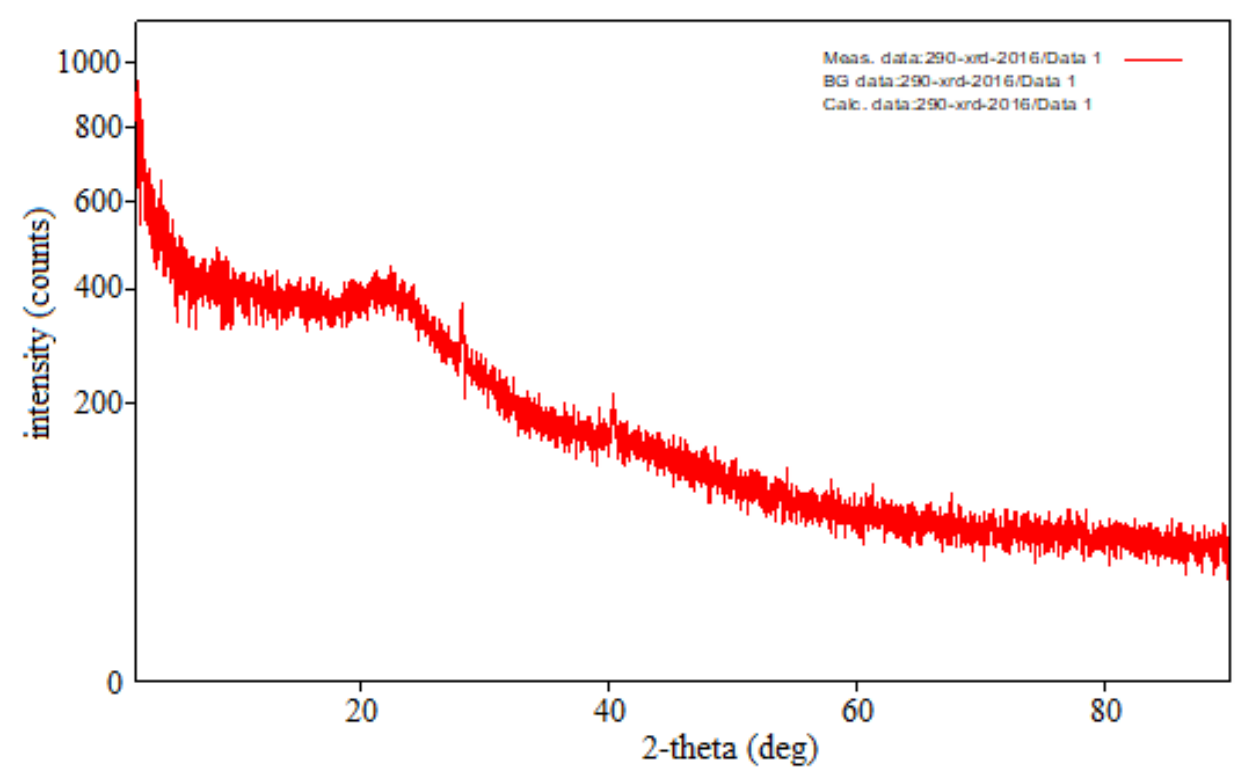

Figure 2. XRD pattern of activated carbon from Salacca zalacca peel

\section{Effect of contact time}

The contact time between the adsorbent and adsorbate is an important parameter in the adsorption process (Osasona, Aiyedatiwa, Johnson, and Faboya, 2018). The effect of contact time on the adsorption of $\mathrm{Cu}$ (II) onto activated carbon from Salacca zalacca peel is described in Figure 3. The adsorption was occurred rapidly in the initial stage and gradually decreased with time until equilibrium was reached (Lee, 2018). The higher adsorption rate at the initial period may be due to less availability of the free active sites on the adsorbent. The equilibrium time was reached at 60 minutes. As time passes, the adsorption rate decreased because the active sites of adsorbent may be occupied so the copper ions were difficult to find binding sites. There was lack of sufficient active sites to accommodate $\mathrm{Cu}(\mathrm{II})$ in the solution.

\section{Effect of Initial Concentration}

The study of the effect of initial concentration is important due to the presence of different concentrations of metal ions in wastewater (RomeroCano, Gonzalez-Gutierrez, Baldenegro-Perez, and Carrasco-Marin, 2017; Tong, and $X u, 2013$ ). Figure 4 shows the effect of the initial concentration on $\mathrm{Cu}$ (II) adsorption using activated carbon. The adsorption capacity increases when the initial $\mathrm{Cu}(\mathrm{II})$ concentration increases. The increase of initial concentrations results in a concentration gradient as a driving force to defeat resistance of the mass transfer of $\mathrm{Cu}$ (II) between aqueous and solid phases during the adsorption process (Semercioz, Gogus, Celwkli, and, Bozkurt 2017). Interaction probability of $\mathrm{Cu}(\mathrm{II})$ with the surface of the activated carbon increases in high $\mathrm{Cu}$ (II) concentration. At this condition, the ratio of available active sites to initial adsorbate concentration is high but at higher adsorbate concentration the ratio becomes lower because the active sites has already saturated with adsorbate (Rehab et al., 2016; Arshadi, Amiri, and Mausavi, 2014).

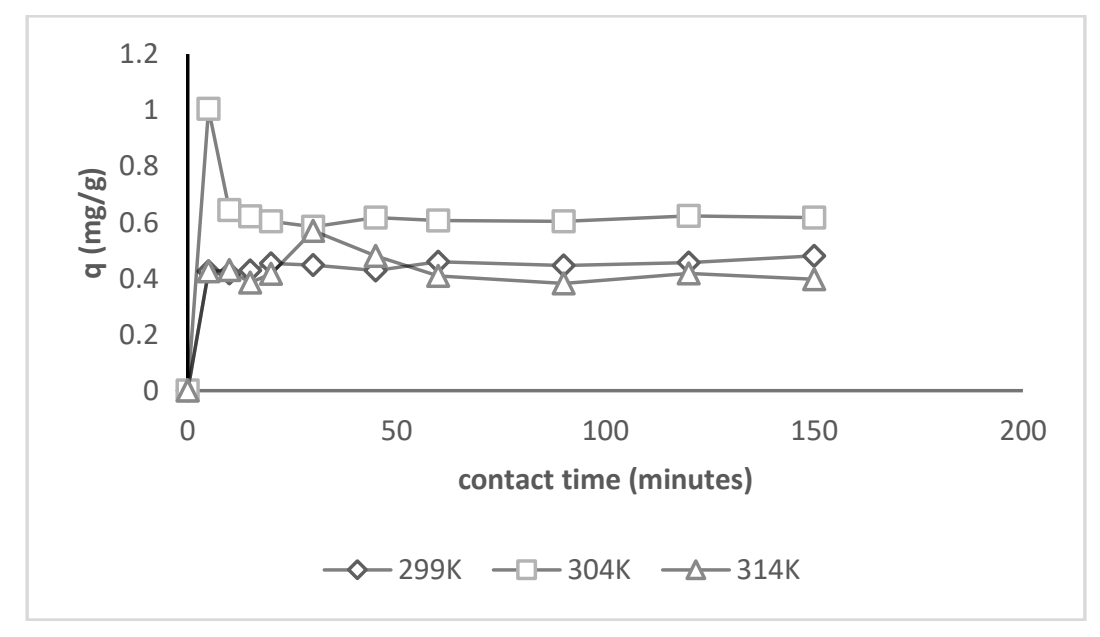

Figure 3. Effect of contact time to the adsorption capacity of carbon on the $\mathrm{Cu}$ (II) adsorption 


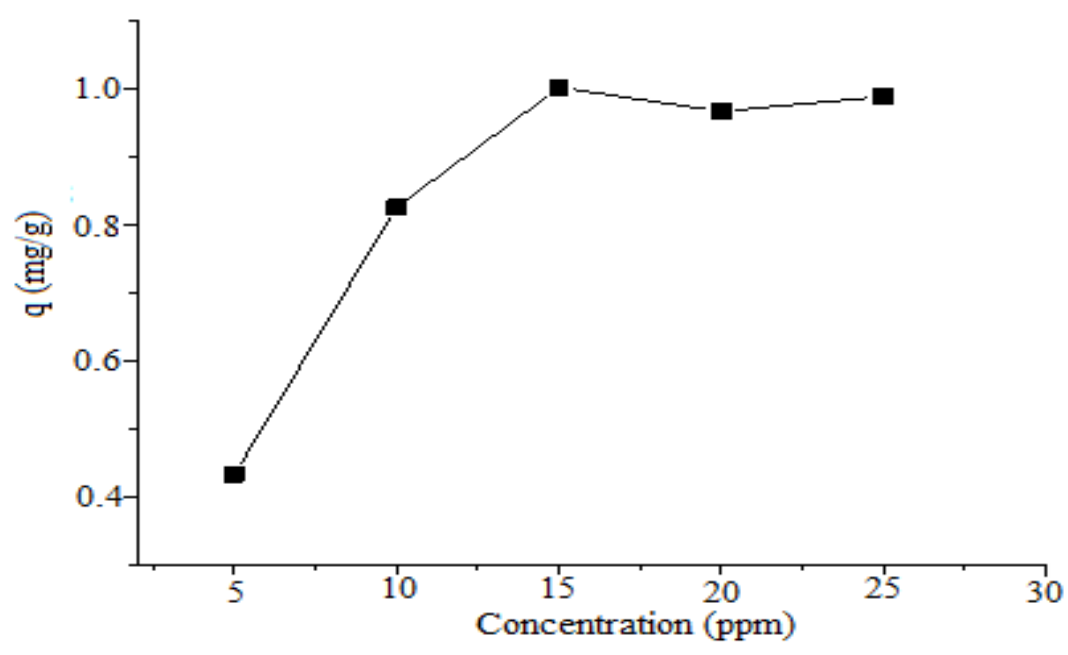

Figure 4. Effect of initial concentration to the adsorption capacity of carbon on the $\mathrm{Cu}(\mathrm{II})$ adsorption

\section{Adsorption isotherm}

Adsorption isotherm data is needed to understand the mechanism of the metal ion adsorption. The adsorption isotherm could describe the interaction of the adsorbate with the adsorbent. This could be used to optimize the use of adsorbent (Khawaja, Mubarak, Zia-Ur-Rehman, Kazi, and Hamid, 2015). The equilibrium data of adsorption of $\mathrm{Cu}(\mathrm{II})$ on activated carbon and the unadsorbed $\mathrm{Cu}$ (II) in solution were analyzed using Langmuir and Freundlich isotherm models. Figure 5 and Figure 6 describe the Langmuir and the Freundlich model for $\mathrm{Cu}(\mathrm{II})$ adsorption onto activated carbon. The equation of Langmuir adsorption isotherm is written as follows.

$$
\frac{C_{e}}{q_{e}}=\frac{1}{q_{m} b}+\frac{1}{q_{m}} C_{e}
$$

Where $q_{e}(\mathrm{mg} / \mathrm{g})$ is the amount of metal ion adsorbed at equilibrium. $C_{e}$ is the equilibrium concentration of adsorbate in the liquid phase. The $Q_{m}(\mathrm{mg} / \mathrm{g})$ is the maximum adsorption capacity corresponding to complete monolayer coverage on the surface. The B $(\mathrm{l} / \mathrm{mg})$ is the Langmuir constant related to the energy of the adsorption (Ghosal, and Gupta, 2017). The slope and intercept of the Langmuir equation can be used to calculate the values of $\mathrm{q}_{\max }$ and $\mathrm{b}$. The linear plot of $\frac{C_{e}}{q_{e}}$ vs $C_{e}$ from Langmuir equation has a slope of $\frac{1}{q_{m}}$ and intercept of $\frac{1}{q_{m} b}$. (Lai, Teo, Wahidin, and Annuar, 2016). The separation factor $R_{L}$ indicates essential characteristic of the Langmuir isotherm equation. The $R_{L}$ equation can be expressed as follows (Patiha, Heraldy, Hidayat, Firdaus, 2016):

$$
R_{L}=\frac{1}{1+b C o}
$$

Where $b$ is Langmuir constant and $C_{0}$ is the initial concentration of $\mathrm{Cu}(\mathrm{II})$. The $\mathrm{R}_{\mathrm{L}}$ value expresses whether adsorption is irreversible $\left(R_{L}=0\right)$, favorable $\left(0<R_{L}<1\right)$, linear $\left(R_{L}=1\right)$ or unfavorable $\left(R_{L}>1\right)$. The Freundlich isotherm model applies to multilayer adsorption. This model assumes that the surface of adsorbent is heterogeneous. The interactions among adsorbate molecules are possible. The Freundlich isotherm equation can be written as follows (Nanta, Kasemwong, and Skolpap, 2018):

$$
\log q_{e}=\frac{1}{n_{f}} \log C_{e}+\log k_{f}
$$

Where $q_{e}(\mathrm{mg} / \mathrm{g})$ is the amount of a metal ion adsorbed at the equilibrium, $C_{e}(\mathrm{mg} / \mathrm{g})$ is the concentration of metal ion in the liquid phase at the equilibrium, $k_{f}(\mathrm{mg} / \mathrm{g})(\mathrm{L} / \mathrm{mg})^{1 / n}$ is Freundlich constant indicated the adsorption capacity, and $n_{f}$ is Freundlich constant related to adsorption intensity. The values of $\frac{1}{n_{f}}$ and $\log k_{f}$ can be obtained from slope and intercept of the plot of $\log q_{e}$ vs $\log C_{e}$. The value of $n_{f}$ indicated the favourability of adsorption (Balaz, Ficeriova, and Briancin, 2016). The values of $n_{f}$ in the range $<1$ indicate poor adsorption, 1-2 moderately difficult, 2-10 represent well. The calculated values of the Langmuir and Freundlich model's parameters are given in Table 1. The correlation coefficients values $\left(R^{2}\right)$ of the Langmuir and Freundlich models show that the adsorption of $\mathrm{Cu}$ (II) onto activated carbon yields a better fit for the Langmuir isotherm model. The Langmuir isotherm model has an $\mathrm{R}^{2}$ value closer to 1 than the Freundlich isotherm model (Chaidir, Furqani, Zein, and Munaf, 2015; Tarmizi et al., 2016;). This result indicates that monolayer coverage has been occurred. This also means that the surface of activated carbon is uniform (the sites are equivalent) and the adsorbed copper molecules do not interact. Table 2 shows that the values of $R_{L}$ for $\mathrm{Cu}(\mathrm{II})$ adsorption onto activated carbon are in a range of $0-1$ which indicated that the adsorption process is favorable according to the Langmuir isotherm. Romero-Cano et al. (2017) reported that adsorption of $\mathrm{Cu}$ (II) using orange peel and pineapple peel gives a better fit for the Langmuir isotherm model. Similarly, in the study of Cu (II) removal using peanut hull (Rehab et al., 2016) and $\mathrm{Cu}$ (II) removal using barley straw ash (Arshadi et al., 2014), the adsorption also followed the Langmuir isotherm model. 


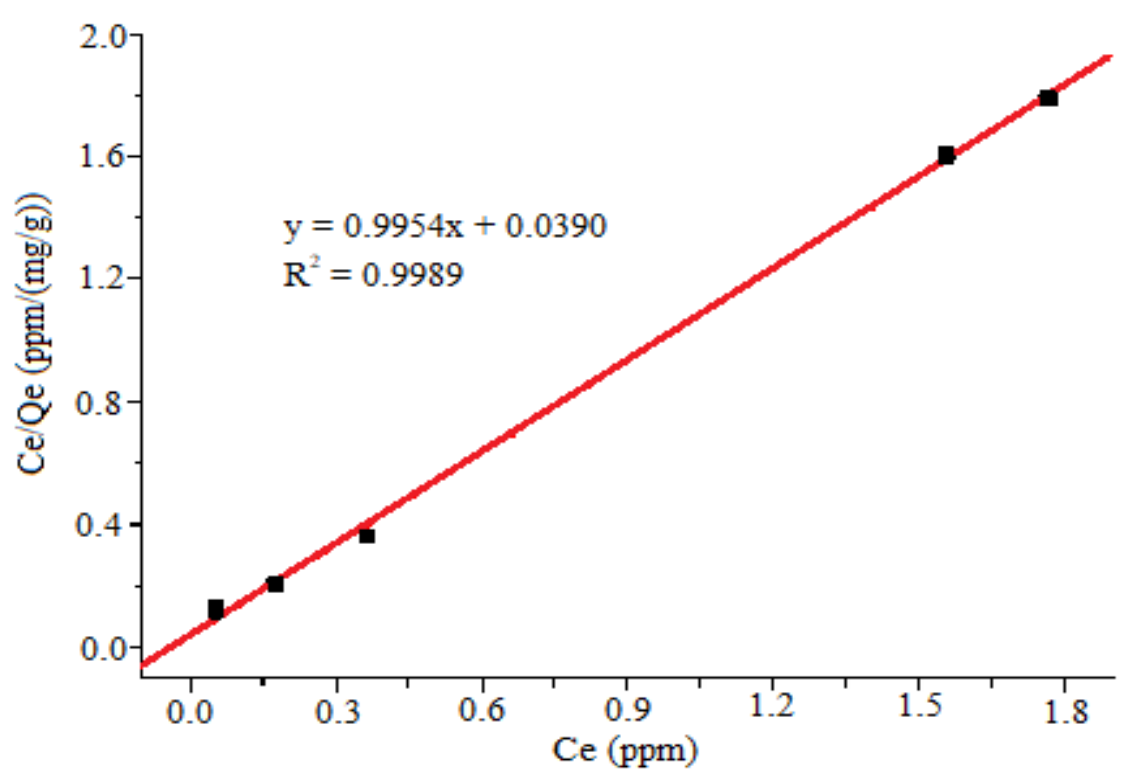

Figure 5. The Langmuir isotherm model

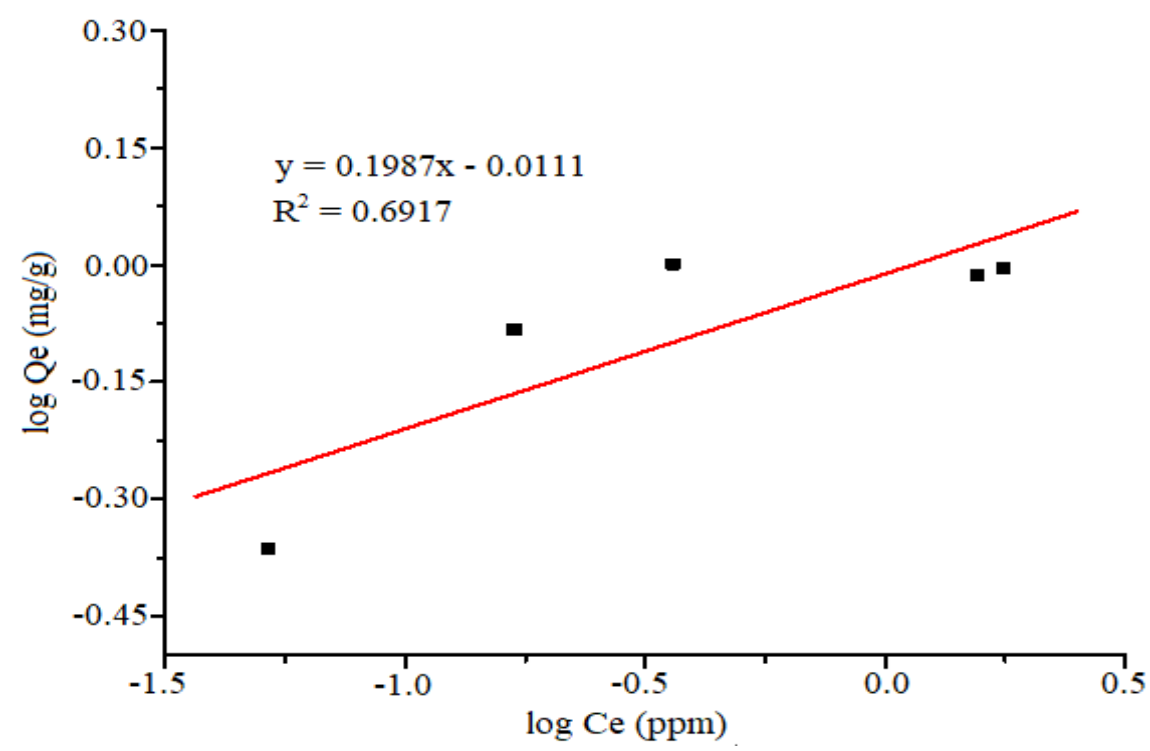

Figure 6. The Freundlich isotherm model

Table 1 The Parameters of Langmuir and Freundlich isotherm models

\begin{tabular}{ccc}
\hline Isotherm Parameter & Langmuir Isotherm & Freundlich Isotherm \\
\hline$q_{\max }$ & 1.0046 & - \\
$\mathrm{B}$ & 25.5236 & - \\
$\mathrm{n}_{\mathrm{f}}$ & - & 5.0327 \\
$\mathrm{~K}_{\mathrm{f}}$ & - & 0.9748 \\
$\mathrm{R}^{2}$ & 0.9989 & 0.6917 \\
\hline
\end{tabular}

Table 2. The $R_{L}$ values at a different initial concentration

\begin{tabular}{ll}
\hline Co $(\mathrm{mg} / \mathrm{L})$ & $\mathrm{R}_{\mathrm{L}}$ \\
\hline 5 & 0,0078 \\
10 & 0.0039 \\
15 & 0.0027 \\
20 & 0.0020 \\
25 & 0.0016 \\
\hline
\end{tabular}




\section{Kinetics Studies}

The kinetics of adsorption describes the adsorption rate and the mechanisms of $\mathrm{Cu}$ (II) adsorption onto activated carbon. Adsorption process occurs in three steps. First, the adsorbate transport from the bulk solution to external surface of the adsorbent. This process called the external mass transfer. Second, the adsorbent does internal diffusion to the active sites of the adsorbent, and third, the adsorption occurrs. There are several kinetic models in the adsorption process. Some models suppose that the rate-determining step is the diffusion process but others predict that the adsorption is the rate-determining step (Largitte and Pasquier, 2016). In this work, the kinetics of adsorption was investigated using two kinetic models which are pseudo-first-order and pseudo-secondorder. These models are commonly used to evaluate the adsorption kinetic of heavy metal pollutants onto adsorbent (Simonin, 2016). The correlation coefficients $\left(\mathrm{R}^{2}\right)$ of pseudo-first-order are compared to pseudo-second-order. The kinetic model which has a correlation coefficient closer to unity is chosen as a kinetic model for $\mathrm{Cu}$ (II) adsorption onto activated carbon from Salacca zalacca peel.

1. Pseudo-first-order

Langergren proposed a kinetic model namely pseudo-first-order kinetic. This kinetic model explains that the adsorption rate is directly proportional to the number of vacant sites (Diordjevic, Stojiljkovic, and Smelcerovic, 2014). Largitte and Pasquier (2016) stated that the process can be written as:

$$
\mathrm{S}+\mathrm{M} \rightarrow \mathrm{MS}
$$

$S$ is adsorbent site and $M$ is adsorbate.

The equation can be written as:

$$
\ln \left(q_{e}-q_{t}\right)=\ln q_{e}-k_{1} t
$$

Where $q_{e}(\mathrm{mg} / \mathrm{g})$ is the amount of adsorbate adsorbed on the surface of adsorbent at equilibrium, $q_{t}(\mathrm{mg} / \mathrm{g})$ is the amount of adsorbate adsorbed on the surface of adsorbent at $t$ time $(\mathrm{min})$ and $k_{1}$ is the pseudo-firstorder rate constant $\left(\mathrm{min}^{-1}\right)$. The value of $k_{1}$ is evaluated from the slopes of plot $\ln \left(q_{e}-q_{t}\right) \mathrm{vs} t$ and $q_{e}$ is evaluated from the intercept of plot $\ln \left(q_{e}-q_{t}\right)$ vs $t$. Figure 7, 9 and 11 show pseudo-first-order kinetic

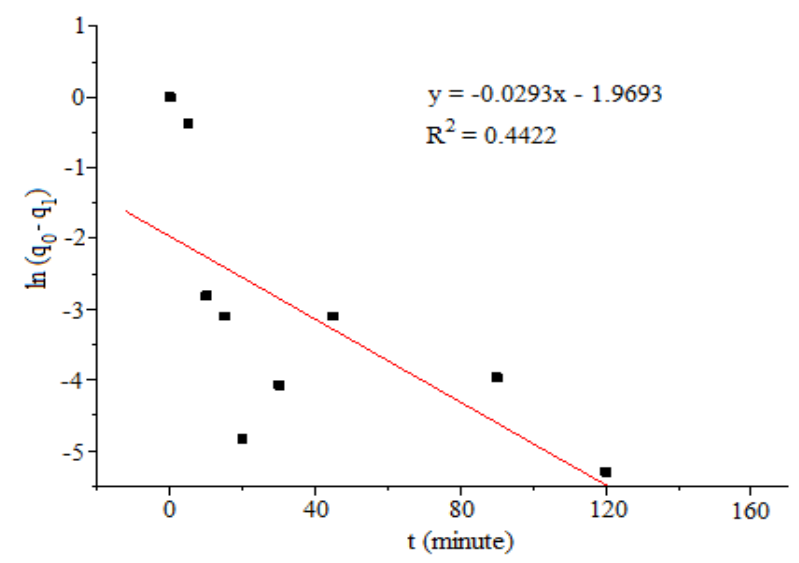

Figure 7. Pseudo-first-order model at $299 \mathrm{~K}$ model for $\mathrm{Cu}$ (II) adsorption using activated carbon from Salacca zalacca peel at 299, and 304K.

2. Pseudo-second-order kinetic model

Pseudo-second-order kinetic model for adsorption was proposed by $\mathrm{Ho}$ and Mc Kay. According to Largitte and Pasquier (2016), the process is:

$$
2 \mathrm{~S}+\mathrm{M} \rightarrow \mathrm{MS}_{2}
$$

$S$ is an active site of adsorbent and $M$ is adsorbate.

The equation is given as follow:

$$
\frac{t}{q_{t}}=\frac{1}{k_{2} q_{e}^{2}}+\frac{t}{q_{e}}
$$

Where $q_{e}(\mathrm{mg} / \mathrm{g})$ is the amount of adsorbate adsorbed on the surface of adsorbent at equilibrium, $q_{t}(\mathrm{mg} / \mathrm{g})$ is the amount of adsorbate adsorbed on the surface of adsorbent at t time ( $\min )$, and $k_{2}$ is the pseudo-second-order rate constant $\left(\mathrm{g} \mathrm{mg}^{-1} \mathrm{~min}^{-1}\right)$. The values of pseudo-second-order rate constant $\left(k_{2}\right)$ are determined from the intercept of a plot of $\frac{t}{q_{t}}$ versus $t$, and $\mathrm{q}_{\mathrm{e}}$ is evaluated from slope of plot of $\frac{t}{q_{t}}$ versus $t$.

The Pseudo-second-order kinetic model explains that the rate of occupation of active sites is proportional to the square of the number of vacant sites. Figures $\mathbf{8}$, 10, and 11 show the pseudo-second-order kinetic model for $\mathrm{Cu}(\mathrm{II})$ adsorption using activated carbon at 299 and $304 \mathrm{~K}$.

Table 3 indicates that the values of the correlation coefficient $\left(\mathrm{R}^{2}\right)$ for the pseudo-second-order are closer to one than the pseudo-first-order. This concludes that the pseudo-second-order gives a better fit than the pseudo-first-order kinetic model. This result indicated that the rate-determining step is the adsorption process, not the diffusion process (Largitte and Pasquier, 2016). In pseudo-second-order model, the rate determining step is chemisorption (chemical adsorption) which involve valence forces through sharing or transfer electrons between adsorbate and adsorbent to form a chemical bond (Arshadi et al., 2014). Similarly, in the study of Cu (II) removal using peanut hull Rehab et al. (2016) reported that the pseudo-second-order gives better describe than pseudo-first-order. Mureed et. al. (2012) stated that adsorption of $\mathrm{Zn}$ (II) using biomass of corncob followed the pseudo-second-order kinetic model.

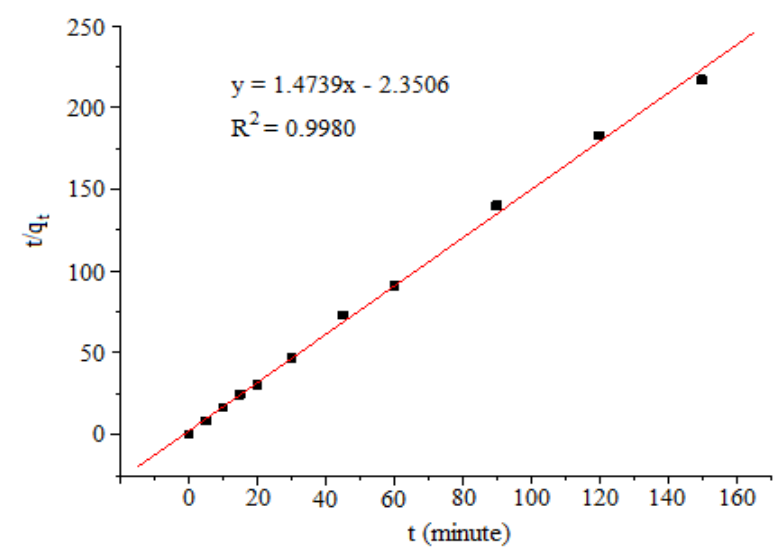

Figure 8. Pseudo-second-order model at $299 \mathrm{~K}$ 


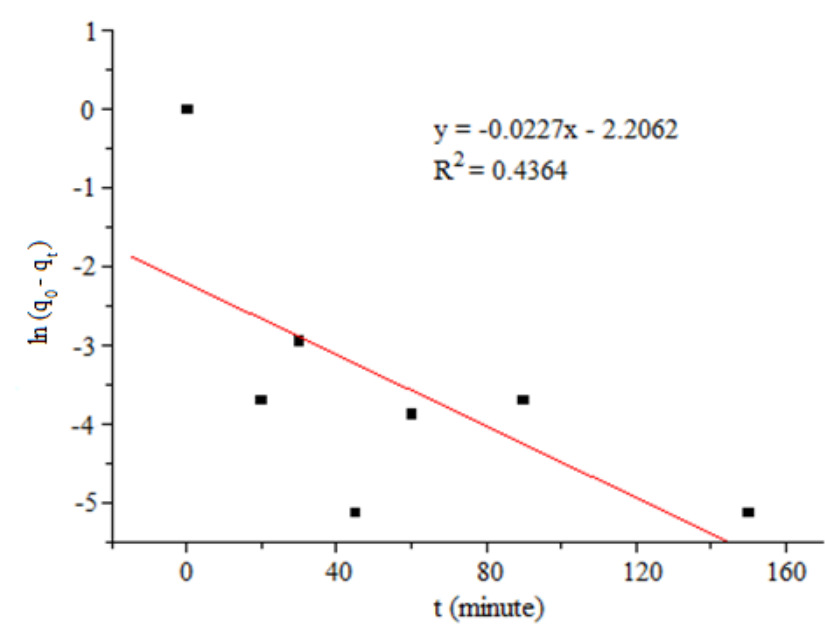

Figure 9. Pseudo-first-order model at $304 \mathrm{~K}$

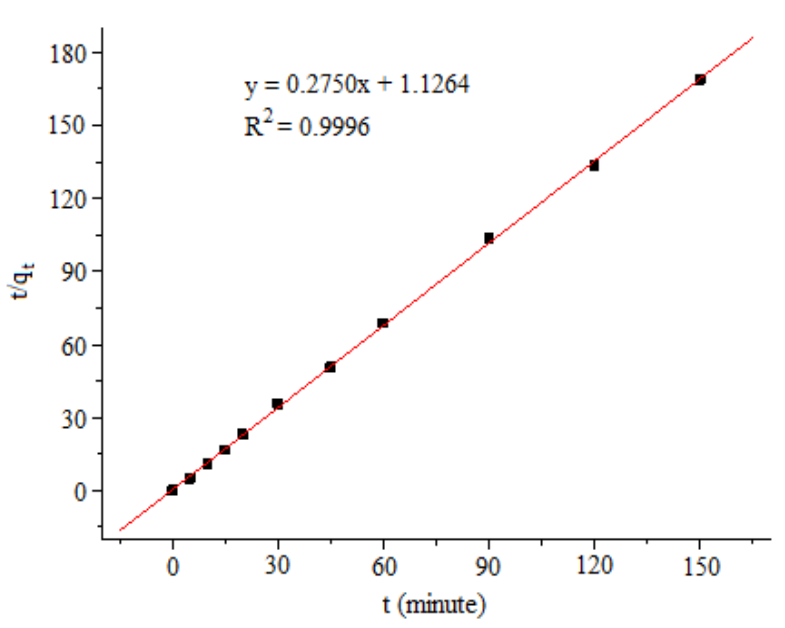

Figure 10. Pseudo-second-order model at $304 \mathrm{~K}$

Table 3. Kinetic parameters

\begin{tabular}{ccllccc}
\hline & \multicolumn{3}{c}{ Pseudo-first-order } & \multicolumn{3}{c}{ Pseudo-second-order } \\
\hline $\mathrm{T}$ & $\mathrm{k}_{1}$ & $\mathrm{Qe}$ & $\mathrm{R}_{1}{ }^{2}$ & $\mathrm{k}_{2}$ & $\mathrm{Qe}$ & $\mathrm{R}_{2}{ }^{2}$ \\
\hline 299 & 0.0293 & 0.1396 & 0.4422 & 0.9242 & 0.6785 & 0.9980 \\
304 & 0.0227 & 0,1101 & 0.4364 & 0.0671 & 3.6364 & 0.9996 \\
314 & 0.0137 & 0.1136 & 0.2330 & -2.0774 & 0.5769 & 0.9963 \\
\hline
\end{tabular}

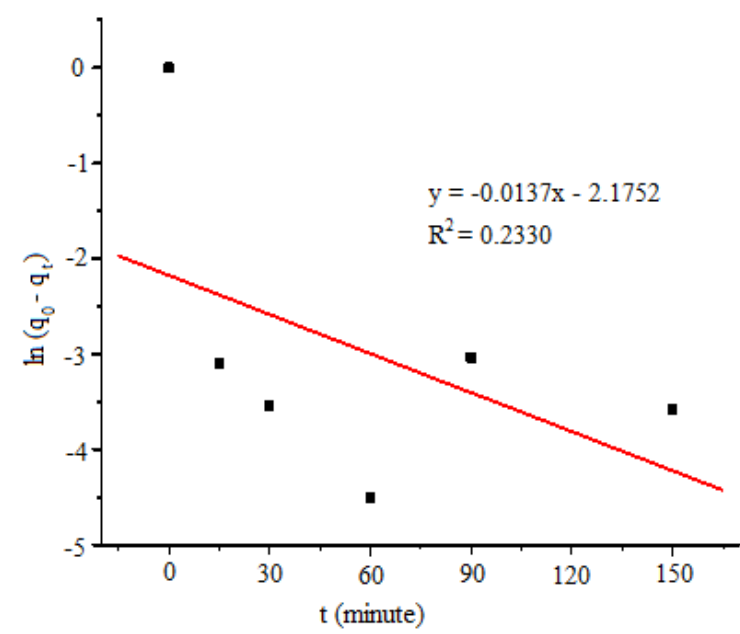

Figure 11. Pseudo-first-order model at $314 \mathrm{~K}$

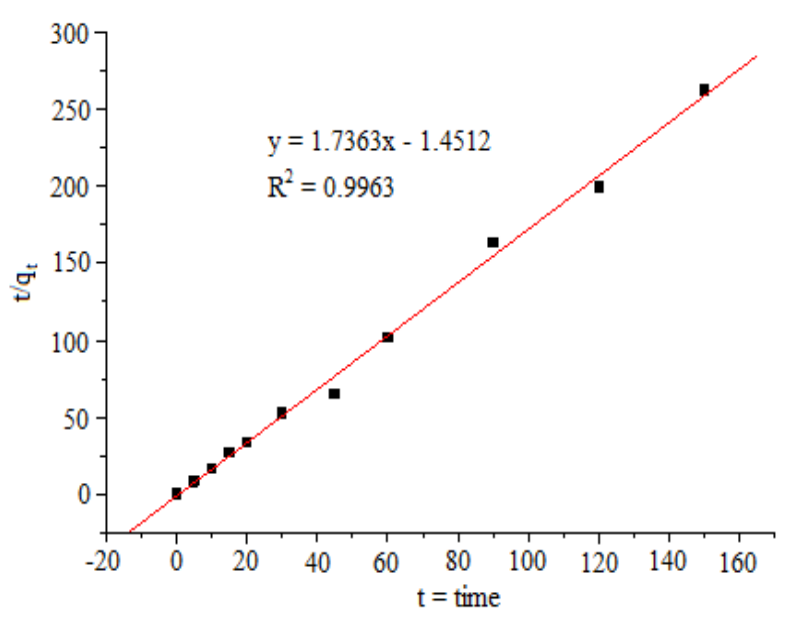

Figure 12. Pseudo-second-order model at $314 \mathrm{~K}$

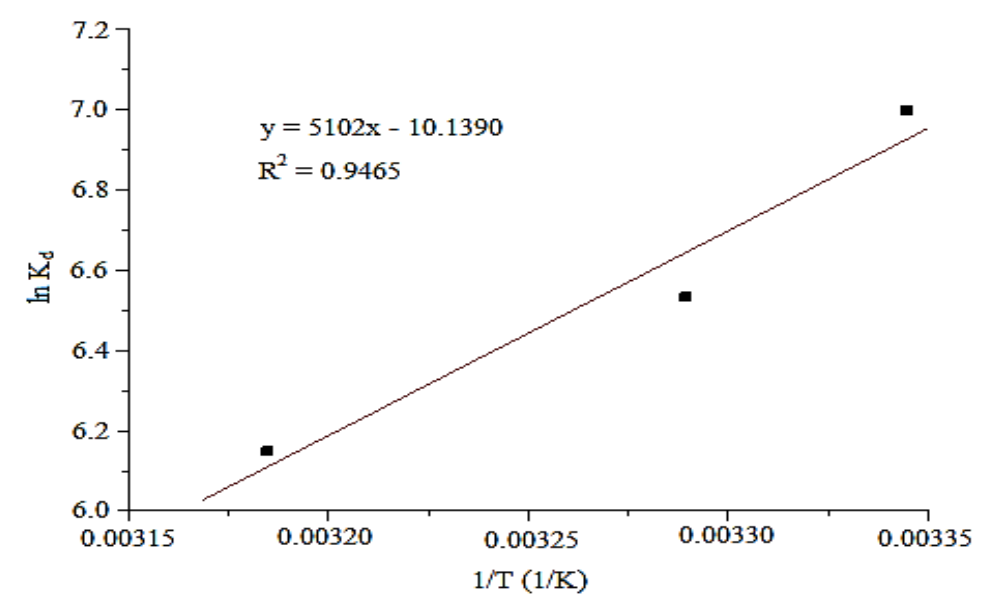

Figure 13. Plot $\ln \mathrm{Kd}$ versus $1 / \mathrm{T}$ 
Table 4 Thermodynamic parameter

\begin{tabular}{cccc}
\hline \multicolumn{4}{c}{ Activated carbon from Salacca zalacca peel } \\
\hline Temperature $(\mathrm{K})$ & $\Delta \mathrm{G}^{\circ} \mathrm{kJ} / \mathrm{mol}$ & $\Delta \mathrm{H}^{\circ} \mathrm{kJ} / \mathrm{mol}$ & $\Delta \mathrm{S}^{\circ} \mathrm{kJ} / \mathrm{mol}$ \\
\hline 299 & -17.396 & & \\
304 & -16.509 & -42.4180 & -0.0843 \\
314 & -16.049 & & \\
\hline
\end{tabular}

\section{Adsorption Thermodynamic}

The thermodynamic parameters are evaluated to understand the spontaneity and the enthalpy change of the adsorption. The thermodynamic parameter is temperature-dependent. The basic thermodynamic parameters are the Gibbs free energy of adsorption $\left(\Delta G^{\circ}\right)$, the enthalpy change $\left(\Delta H^{\circ}\right)$, and the entropy change $\left(\Delta S^{\circ}\right)$. The value of Gibbs free energy $\left(\Delta G^{\circ}\right)$ indicates the spontaneity of the adsorption process. The adsorption process is spontaneous if the value of Gibbs free energy $\left(\Delta G^{\circ}\right)$ is negative. The value of $\Delta H^{\circ}$ gives information whether the adsorption is exothermic or endothermic. The adsorption process is exothermic if the value of $\Delta \mathrm{H}^{\circ}$ is negative and the adsorption process is endothermic if the value of $\Delta \mathrm{H}^{\circ}$ is positive (Denayer, and Baron, 2005; Miawnowski, and Urbanczyk, 2017). The value of $\Delta S^{\circ}$ related to the degree of freedom of the adsorbed species.

The thermodynamic parameters were evaluated using equations as follows:

$$
\begin{aligned}
& K_{d}=\frac{q_{e}}{C_{e}} \\
& \Delta G^{\circ}=-R T \ln K_{d} \\
& \ln K_{d}=\frac{\Delta S^{\circ}}{R}-\frac{\Delta H^{\circ}}{R T}
\end{aligned}
$$

Where $\mathrm{K}_{\mathrm{d}}$ is the equilibrium adsorption constant, $q_{e}$ is metal ion concentration at equilibrium $(\mathrm{mg} / \mathrm{g})$, and, $C_{e}$ is metal ion concentration in solution at equilibrium $(\mathrm{mg} / \mathrm{l})$. The $\Delta G^{\circ}$ is the standard Gibbs free energy $\left(\mathrm{kJmol}^{-1}\right), \mathrm{R}$ is gas constant $\left(8.314 \mathrm{Jmol}^{-1} \mathrm{~K}^{-1}\right), \mathrm{T}$ is the temperature (K), $\Delta H^{o}$ is standard enthalpy $\left(\mathrm{Jmol}^{-1}\right)$ and $\Delta \mathrm{S}^{\circ}$ is standard entropy $\left(\mathrm{Jmol}^{-1} \mathrm{~K}^{-1}\right)$. The value of $\Delta \mathrm{H}^{\circ}$ and $\Delta \mathrm{S}^{\circ}$ could be determined from slope and intercept of the plot of $\ln K_{d}$ versus 1/T. Figure 13 describes the plot of $\ln K_{d}$ versus 1/T.

In this study, the values of $\Delta G^{\circ}$ are negative. This negative value revealed that the adsorption of $\mathrm{Cu}(\mathrm{II})$ onto activated carbon from Salacca zalacca peel is occurred spontaneously. The value of $\Delta G^{\circ}$ gives information on whether the adsorption is controlled by physical or chemical adsorption. The physical adsorption is occurred if the value of $\Delta G^{\circ}$ is until -20 $\mathrm{kJmol}^{-1}$ and chemical adsorption occurred if the value of $\Delta \mathrm{G}^{\circ}$ more negative than $-40 \mathrm{kJmol}^{-1}$ (Osasona et al., 2018). In this research, the values of $\Delta G^{\circ}$ ie 17.396, -16.509, -16.049 $\mathrm{kJmol}^{-1}$ at $T=299,304$, $314 \mathrm{~K}$, respectively. Based on $\Delta \mathrm{G}^{\circ}$ values, it could be concluded that adsorption of $\mathrm{Cu}(\mathrm{II})$ onto activated carbon from Salacca zalacca peel is controlled by physical adsorption. The negative value of $\Delta \mathrm{H}^{\circ}$ suggests that the adsorption of $\mathrm{Cu}(\mathrm{II})$ onto activated carbon is exothermic. The value of $\Delta S^{\circ}$ in this study is negative. This could be considered that in the adsorption of $\mathrm{Cu}$ (II) onto activated carbon, the degree of disorder at solid-liquid interface decreased. The negative value of $\Delta \mathrm{S}^{\circ}$ means the decrease in the degree of freedom of the adsorbed species. Similar results were obtained in the previous work. Othman et al. (2011) stated that the adsorption of Cd (II) by modified agricultural waste has negative values of $\Delta \mathrm{G}^{\circ}, \Delta \mathrm{H}^{\circ}, \Delta \mathrm{S}^{\circ}$. The absolute small value of Gibbs free energy indicated that the adsorption of $\mathrm{Cd}$ (II) by modified agricultural waste was controlled by physisorption. Balarak, Azarpira, \& Mostafapour (2016) also reported the negative values of $\Delta \mathrm{G}^{\circ}, \Delta \mathrm{H}^{\circ}$, $\Delta \mathrm{S}^{\circ}$ in the $\mathrm{Cd}$ (II) removal by adsorption using barley husk. Table 4 shows the thermodynamic parameter of $\mathrm{Cu}(\mathrm{II})$ adsorption using activated carbon from Salacca zalacca peel.

\section{CONCLUSIONS}

The $\mathrm{Cu}(\mathrm{II})$ ion adsorption equilibrium was reached after 60 minutes of contact time. The adsorption data had a better fitting line for the Langmuir isotherm model. From the value of $R^{2}$, it seemed that the adsorption process obeyed a second-order kinetics model. The Thermodynamic parameters were determined $\left(\Delta \mathrm{H}^{\circ}=-42.4180 \mathrm{~kJ} / \mathrm{mol} ; \Delta \mathrm{S}^{\circ}=-0.0843\right.$ $\left.\mathrm{kJ} / \mathrm{mol} ; \Delta \mathrm{G}^{\circ}<0\right)$. These values suggested that the adsorption of $\mathrm{Cu}$ (II) by activated carbon from salacca peel was exothermic and spontaneous. The small absolute value for $\Delta G^{\circ}$ indicated that the main mechanism controlling the adsorption process was physisorption.

\section{ACKNOWLEDGMENTS}

The authors acknowledge the Universitas Negeri Yogyakarta for funding this work and supporting research facilities in the laboratory.

\section{REFERENCES}

Arshadi,M., Amiri, M.J., \& Mousavi, S. (2014). Kinetic, equilibrium and thermodynamic investigations of $\mathrm{Ni}$ (II), $\mathrm{Cd}(\mathrm{II}$ (, $\mathrm{Cu}(\mathrm{II})$, and $\mathrm{Co}(\mathrm{II})$ adsorption on barley straw ash. Water Resources and Industry 6, 1-17.

Balarak, D., Azarpira, H., \& Mostafapour, F., K. (2016). Thermodynamic of removal of cadmium by adsorption on Barley husk biomass. Der Pharma Chemica 8, 243-247. 
Balaz, M., Ficeriova, J., \& Briancin, J. (2016). Influence of milling on the adsorption ability of eggshell waste. Chemosphere 146, 458-471.

Bradl. H. (2015). Encyclopedia of Surface and Colloid Science. Boca Raton: CRC Press.

Brown, P., Jefcoat, I.A., Parrish, D., Gill, S., \& Graham, E. (2000). Evaluation of the adsorptive capacity of peanut hull pellets for heavy metals in solution. Advances in Environmental Research. 4, 19-29.

Chaidir, Z., Furgani, F., Zein, R., \& Munaf, E. (2015). Utilization of Annona muricata L. seeds as potential adsorbents for the. Journal of Chemical and Pharmaceutical Research 7, 879888.

Chao, H.P. , \& Chang, C.C. (2018). Adsorption of copper(II), cadmium(II), nickel(II) and lead(II) from aqueous solution using biosorbents. Adsorption, 395-401.

Denayer, J.F.M., \& Baron, G.V. (2005). The confinement factor: A thermodynamic parameter to characterize microporous adsorbents. Adsorption 11, 85-90.

Djordjevic, D., Stojiljkovic, D., \& Smelcerovic, M. (2014). Adsorption kinetics of reactive dyes on ash from town heating plant. Archives of Environmental Protection 40, 123-135.

Enniya, I., Rghioui, L., \& Jourani, A. (2018). Adsorption of hexavalent chromium in aqueous solution on activated carbon prepared from apple peels. Sustainable Chemistry and Pharmacy 7, 9-16.

Fang,L., Li,L., Qu, Z., Xu, H., Xu, J., \& Yan, N. (2018). A novel method for the sequential removal and separation of multiple heavy metals from wastewater. Journal of Hazardous Matterials, 617-624

Ghosal, P.S., \& Gupta, A.K. (2017). Determination of thermodynamic parameters from Langmuir isotherm constant-revisited. Journal of Molecular Liquid 225, 137-146.

Gueu, S, Yao, B., Adouby, K, \& Ado, G. (2007). Kinetics and thermodynamics study of lead adsorption on to activated carbons from coconut and seed hull of the palm tree. International Journal of Environmental Science and Technology 4, 11-17.

Gueu, S., Yao, B., Adouby, K., \& Ado, G. (2006). Heavy metals removal in aqueous solution by activated carbons prepared from coconut shell and seed shell of the palm tree. Journal of Applied Science 6, 2789-2793.

Indhumathi,P., Sathiyarai, S., Koelmel, J.P., Jayabalakrishnan, C., \& Saravanabhavan, M. (2018). The efficient removal of heavy metal ions from industry effluents using waste biomass as low-cost adsorbent: thermodynamic and kinetic models. Zeitschrift für Physikalische Chemie 232, 527-543.
Jaishankar, M., Mathew, B.B., Shah, M..S, Murthy, T.P.K, \& Gowda, K.R.S. (2014). Biosorption of few heavy metal ions using agricultural wastes. Journal of Enviromental Pollution and Human Health 2, 1-6.

Khawaja, M., Mubarak, S., Zia-Ur-Rehman, M., Kazi, A.A., \& Hamid, A. (2015). Adsorption studies of pomegranate peel activated charcoal for nickel (II) ion. Journal of The Chilean Chemical Society $60,2642-2645$

Kolanowska, A., Janas, D., Herman, A.P., Jedrysiak, R.G., Gizewski, T., \& Boncel, S. (2018). From blackness to invisibility - Carbon nanotubes role in the attenuation of and shielding from radio waves for stealthtechnology. Carbon, 31 52.

Kumar, K.Y., Muralidhara, H.B., Nayaka, Y.A., Balasubramanyam, J., \& Hanumanthappa, $\mathrm{H}$. (2013). Low-cost synthesis of metal oxide nanoparticles and their application in adsorption of commercial dye and heavy metal ion in aqueous solution. Powder Technology 246, 125-136.

Kunigk, L., Dos Santos, M.C.R., \& Jurkiewicz, C.,. (2011). Copper ions remotion from sugarcane spirit by activated carbon and ion exchange resins. Acta Scientific 33, 101-106.

Lai, L.W., Teo, C.L., Wahidin, S., \& Annuar, M.S. (2016). Determination of enzyme kinetic parameters on sago starch hydrolysis by linearized graphical methods 2014. The Malaysian Journal of Analytical Science 18, 527-533.

Largitte, L., \& Pasquier,R. (2016). A review of the kinetics adsorption models and their application to the adsorption of lead by an activated carbon. Chemical Engineering Research and Design 109.

Lee, J. (2018). Study on equillibrium, kinetic, thermodynamic parameters for adsorption of brilliant green by zeolite. Korean Chemical Engineering Research. 56, 112-118.

Liv, Q., Li,T.,Zhi,J., \& Ren,B. (2017). treatment of heavy metal containing wastewater by biomass based activated carbon. Modern Chemical Industry, 37.

Mafra, M.R., Igarashi-Mafra, L., Zuim, D.R., Vasques, E.C., \& Ferreira, M.A. (2013). Adsorption of remazol brilliant blue on an orange peel adsorbent. Brazilian Journal of Chemistry Engineering 30, 657-665.

Miawnowski, A.;, \& Urbanczyk, W. (2017). Enthalpyentropy compensation for isosteric state adsorption at near ambient temperatures. Adsorption 23, 831-846.

Mureed, F., Nadeem, R., Mehmood, A.; Siddique, M., \& Bukhari, M. (2012). Biosorption of zinc by chemically modified biomass of corncob (Zea 
mays L.). Middle East Journal of Scientific Research 11.

Nanta, P., Kasemwong, K., \& Skolpap, W. (2018). Isotherm and kinetic modelling on superparamagnetic nanoparticles adsorption of polysaccharide. Journal of Environmental Chemical Engineering 6, 794-802.

Osasona, I. A. (2018). Activated carbon from spent brewery barley husks for cadmium ion adsorption from aqueous solution. Indonesian Journal of Chemistry 18, 145.

Othman, Z.A.A, Hashem, A., \& Habila, M.A. (2011). Kinetic, equilibrium and thermodynamic studies of cadmium (II) adsorption by modified agricultural wastes. Molecules 16, 10443-10456.

Patiha, Heraldy, E., Hidayat, Y., \& Firdaus, M. (2016). The langmuir isotherm adsorption equation: The monolayer approach. IOP Conference Series: Materials and Science and Engineering (vol. 107). IOP Publishing.

Rehab, M.A., Hesham, A.H., Mohamed, M.H., \& Gihan, F.M. (2016). Potential of using green adsorbent of heavy metal removal from aqueous solutions: Adsorption kinetics, isotherm, thermodynamic, mechanism and economic analysis. Journal of Ecological Engineering 91, 317-332.

Romero-Cano, L.A., Gonzalez-Gutierrez, L.V., Baldenegro-Perez, L.A., \& Carrasco-Marin, F. (2016). Grapefruit peels as biosorbent: characterization and use in batch and fixed bed column for $\mathrm{Cu}$ (II) uptake from wastewater. Jounal of Chemical Technology and Biotechnology 92, 1650-1658.
Salman, T.A, \& Ali, M.I. (2016). Potential application of natural and modified orange peel as an eco-friendly adsorbent for methylene blue dye. Iraqi Journal of Science 57, 1-13.

Semercioz, A.S., Gogus, F., Celwkli, A., \& Bozkurt, H. (2017). Development of carbonaceous material from grapefruit peel. Journal of Cleaner Production 165, 599-610.

Shanmugavalli, R., Madhavakrishnan, S., Kadirvelu, K., Rasappan, K., Mohanraj. R., \& Puttabhi, S. (2007). Adsorption studies on removal of $\mathrm{Cr}$ (VI) from aqueous solution using Silk cotton hull carbon. Journal of Industrial Pollution Control 23, 65-72.

Simonin, J. (2016). On the comparison of pseudo-first order and pseudo-second order rate laws in the modeling of adsorption kinetics. Chemical Engineering Journal 300, 254-263.

Tarmizi, A.F.A., Ong, K.K., Yunus, W. M. Z., Fitrianto, A., Jabit, M.L., Hussain, A.G., \& Teoh, C.C. (2016). Sorption isotherm model of zinc (II) onto thermally treated rice husk. Oriental Journal of Chemistry 32, 2797-2801.

Tong, X., \& Xu, R. (2013). Removal of Cu(II) from acidic electroplating effluent by biochars generated. Journal of Environmental Sciences 25, 652-658.

Zhigang Xie, Wei Guan, Fangying Ji, Zhongrong Song, \& Yanling Zhao. (2014). Production of Biologically Activated Carbon from Orange Peel and Landfill Leachate Subsequent Treatment Technology. Journal of chemistry, 1-9. 